\title{
CORRELATION OF SANITATION HOUSE CONDITIONS, DRINKING WATER ACCESS, AND HEALTHY CLEAN BEHAVIOUR WITH DIARRHOEA
}

\author{
Korelasi Kondisi Sanitasi Rumah, Akses Air Minum dan Perilaku Hidup Bersih Sehat dengan Kejadian \\ Diare
}

\section{Dewi Lusyana Sari}

Public Health Faculty, Universitas Airlangga, dewi.lusyana.sari-2015@fkm.unair.ac.id Corresponding Author: Dewi Lusyana Sari, dewi.lusyana.sari-2015@fkm.unair.ac.id, Department of Epidemiology, Public Health Faculty, Universitas Airlangga, Dr. Ir. H. Soekarno Street, Mulyorejo, Surabaya City, East Java, Indonesia, Postal Code 60115

\section{ARTICLE INFO}

Article History:

Received May, $15^{\text {th }}, 2019$

Revised form June, $21^{\text {st }}, 2019$

Accepted September, $27^{\text {th }}, 2019$

Published onlineSeptember, $30^{\text {th }}$, 2019

\author{
Keywords: \\ sanitation house conditions; \\ drinking water access; \\ clean and healthy living behaviour; \\ diarrhoea; \\ probolinggo district
}

\section{Kata Kunci:}

kondisi sanitasi rumah;

akses air minum;

perilaku hidup bersih sehat;

diare;

kabupaten probolinggo

\begin{abstract}
Background: The incidence of diarrhoea is still a public health problem in various districts or cities in East Java Province. The prevalence of diarrhoea in Probolinggo Regency in 2017 was $2.43 \%$. Purpose: This study aims to determine the strong relationship between conditions of home sanitation, drinking water access, and clean and healthy living behaviour with the incidence of diarrhoea in Probolinggo District. Methods: This is an observational analytic study with a correlation study design. The population used was all diarrhoea patients treated by health workers from all health centres in each subdistrict in Probolinggo in 2017. The variables studied included the percentage of home sanitation conditions, drinking water access, clean and healthy living behaviour, and prevalence of diarrhoea from all puskesmas (government health clinics) in the district of Probolinggo. The data analysis technique used was Pearson correlation. Results: The prevalence of diarrhoea in Probolinggo Regency decreased in the three years 2015 to 2017, with Bago Health Centre contributing the highest number of cases. This study shows a very weak correlation between the conditions of home sanitation (0.07), drinking water access (0.02), and clean and healthy living behaviour (0.03) and the incidence of diarrhoea. Conclusion: In 2017 there was a very weak correlation between the conditions of home sanitation, drinking water access, and clean and healthy living behaviour with the incidence of diarrhoea in Probolinggo District. The Probolinggo District Health Office and related sectors should pay attention to the dominant factors that have a positive linear correlation direction in order to prevent the incidence of diarrhoea.
\end{abstract}

C2019 Jurnal Berkala Epidemiologi. Published by Universitas Airlangga.

This is an open access article under CC-BY-SA license (https://creativecommons.org/licenses/by-sa/4.0/)

ABSTRAK
Latar Belakang: Kejadian diare masih menjadi masalah kesehatan
masyarakat di berbagai kabupaten atau kota di Provinsi Jawa Timur.
Prevalensi diare di Kabupaten Probolingo tahun 2017 sebanyak


2,43\%. Tujuan: Penelitian ini bertujuan untuk mengetahui kuat hubungan antara kondisi sanitasi rumah, akses air minum, serta perilaku hidup bersih sehat (PHBS) dengan kejadian diare di Kabupaten Probolinggo. Metode: Penelitian ini merupakan penelitian observasional analitik dengan desain studi korelasi. Populasi yang digunakan yaitu semua penderita diare yang ditangani oleh tenaga kesehatan dari seluruh puskesmas setiap kecamatan di Kabupaten Probolinggo tahun 2017. Variabel yang diteliti yaitu persentase kondisi sanitasi rumah, akses air minum, perilaku hidup bersih sehat, serta prevalensi diare dari seluruh puskesmas di Kabupaten Probolinggo dengan teknik analisis data yang digunakan adalah korelasi pearson. Hasil: Prevalensi diare di Kabupaten Probolinggo mengalami penurunan dalam waktu tiga tahun (20152017). Prevalensi diare di Puskemas Bago berkontribusi sebagai angka tertinggi dalam kurun waktu tiga tahun dari tahun 2015 sampai dengan tahun 2017. Penelitian ini menunjukkan terdapat korelasi yang sangat lemah antara kondisi sanitasi rumah $(0,07)$, akses air minum $(0,02)$, dan PHBS $(0,03)$ dengan kejadian diare. Kesimpulan: Terdapat korelasi yang sangat lemah antara kondisi sanitasi rumah, akses air minum, serta PHBS dengan kejadian diare di Kabupaten Probolinggo tahun 2017, sehingga disarankan kepada Dinas Kesehatan Kabupaten Probolinggo dan sektor terkait untuk memperhatikan faktor dominan yang kuat hubunganya memiliki arah korelasi linier yang positif untuk mencegah peningkatan angka kejadian diare.

C2019 Jurnal Berkala Epidemiologi. Penerbit Universitas Airlangga. Jurnal ini dapat diakses secara terbuka dan memiliki lisensi CC-BY-SA (https://creativecommons.org/licenses/by-sa/4.0/)

\section{INTRODUCTION}

Health is an important part of life. A healthy body enables individuals to do the things they want and need to do. Freedom from disease makes it possible to live productively and contribute to the achievement of optimal public health. This achievement is very complex. When individuals want to be free from various diseases, all aspects must be considered - physical, psychological, and social (Na \& Streim, 2017).

Good health is the result of the interaction of various influencing factors. There are four factors that support optimal health: environment, behaviour, health services, and offspring (Blum, 1974). Environment and behaviour have an important role in achieving public health (Mardotillah, Gunawan, Soemarwoto, \& Raksanagara, 2018).

Poor environmental conditions are the main factors that can affect environmental health. Poor environmental conditions trigger various environmental-based diseases (Jannah \& Maftukhah, 2018). Maintenance of the environment needs to be balanced with positive behaviour. An environment that is not properly maintained can have a negative impact in the form of various environmental-based diseases. One of the environmental-based diseases related to environmental sanitation, the existence of vectors, and human behaviour is diarrhoea (Sidhi, Raharjo, \& Dewanti, 2016).

Diarrhoea is a condition that is experienced by a person during defecation. Defecation is frequent and stools are loose and runny. Diarrhoea in Indonesia has become a public health problem that continues to increase and has the potential to be an outbreak (KLB) that can cause death (Ministry of Health RI, 2018).

The case fatality rate (CFR) when diarrhoea breaks out is expected to be $<1 \%$. Outbreak rates for diarrhoea in Indonesia in 2010-17 were above $1 \%$, except for 2011 when it dropped to $0.40 \%$ (Ministry of Health RI, 2018). Health facilities' coverage of diarrhoea patients in Indonesia aims for $10 \%$ of the predicted number of sufferers of all ages. In 2017 there was an increase in the number of patients served in health facilities to 4,274,790, from 3,176,079 sufferers in 2016. The incidence of diarrhoea in East Java Province is still high at 
841,883 cases and that number is the highest among other infectious diseases such as HIV/AIDS, malaria, and sexually transmitted infections (East Java Provincial Health Office, 2018).

Healthy latrine access in Indonesia increased in 2016 by $67 \%$. There are four regencies/cities in East Java Province with proper sanitation: Pacitan, Magetan, Ngawi, and Madiun. Probolinggo Regency is still relatively low for the achievement of proper sanitation (East Java Provincial Health Office, 2018). Healthy toilet access in Probolinggo Regency in 2017 was 67.40\% (Probolinggo District Health Office, 2018).

Disposal of human waste such as urine and stool can affect the quality of water sources. One of the impacts of these conditions is the difficulty of accessing adequate drinking water. This can be a cause of high rates of diseases transmitted through water media, such as diarrhoea (Azhar, Siska, \& Hapsari, 2015). Access to quality (decent) drinking water in Probolinggo Regency in 2017 reached $1,132,513$ people or $97.96 \%$ of the population (Probolinggo District Health Office, 2018).

In addition to environmental factors, behavioural factors also matter. Behaviour contributes to the determination of broad environmental conditions (Megasari, Hidayat, Chairuddin, \& Santoso, 2015). Based on data from a Probolinggo District Health Office report, in 2017 healthy hygiene behaviour was performed by $20,652(24.20 \%)$ households out of a total of 85,284 households monitored (Probolinggo District Health Office, 2018).

This study aims to analyse the strong relationship between conditions of home sanitation, drinking water access, and Perilaku Hidup Bersih dan Sehat (PHBS), meaning clean and healthy living behaviour, with the incidence of diarrhoea in Probolinggo District in 2017

\section{METHODS}

This is an analytic observational research with a correlation study design. The population used consisted entirely of diarrhoea patients treated by health workers from all health centres in each subdistrict in Probolinggo District in 2017. The present study used the total population.

The independent variable in this study is the percentage of home sanitation conditions that meet health requirements including types of closets equipped with covers, septic tank ownership and Wastewater Management Channels (SPAL), facilities that meet physical, microbiological, chemical, and radioactive requirements, and the percentage of PHBS that fulfils 10 healthy household indicators for all family members. These indicators are not smoking in the house, childbirth is assisted by health workers, breastfeeding, weighing babies and toddlers every month, washing hands with clean water and soap, accessing clean water, using clean and healthy latrines, combating mosquito larvae, eating vegetables and fruit every day, and doing physical activity.

This study used secondary data from the health profile of Probolinggo Regency in 2017. It used total sampling of all diarrhoea patients treated by healthcare workers from all health centres in each subdistrict in Probolinggo District in 2017. The dependent variable in this study was the prevalence of diarrhoea from all health centres in Probolinggo Regency in 2017. The independent variables in this study were the condition of houses that met the requirements, access to adequate drinking water, and PHBS. Data analysis used the Kolmogorov-Smirnof test for normality and the Pearson correlation test to determine the relationship between two or more variables.

\section{RESULTS}

\section{Overview of Diarrhoea Occurrence in Health Centres in Probolinggo District from 2015 to 2017}

Diarrhoea can affect all age groups from toddlers to adults. Probolinggo Regency is one of the districts that contributes to the number of diarrhoea cases in East Java Province. This regency has sought to treat the incidence of diarrhoea in the form of oral rehydration solution (ORS) and infusion of patients. ORS is given to diarrhoea patients with mild or moderate dehydration while infusion is only for patients with severe dehydration. Other efforts to tackle diarrhoea include directing the community to conduct positive behaviours in terms of health, assisted by local cadres.

The prevalence of diarrhoea in Probolinggo Regency decreased in the three years 2015 to 2017. It decreased from $2.70 \%$ in 2015 to $2.69 \%$ in 2016, and it decreased again to $2.43 \%$ in 2017 .

From 2015 to 2017, five health centres had the highest prevalence of diarrhoea. Of the five, Bago health centres contributed the most cases, although the prevalence of diarrhoea decreased each year. The health centre with the highest prevalence of diarrhoea for the two years from 
2015 to 2016 was Ranugedang Health Centre with an increase in the prevalence of diarrhoea from $6.52 \%$ to $7.94 \%$ (Table 1 ).

\section{Table 1}

List of Five Health Centres in Probolinggo District with the Highest Prevalence of Diarrhoea in 20152017

\begin{tabular}{clr}
\hline Years & \multicolumn{1}{c}{ Health Centre } & Prevalence \\
\hline 2015 & Bago Health Centre & 10,46 \\
& Ranugedang Health Centre & 6,52 \\
& Curahtulis Health Centre & 4,62 \\
& Tiris Health Centre & 4,37 \\
\multirow{2}{*}{2016} & Wonomerto Health Centre & 4,27 \\
& Ranugedang Health Centre & 7,94 \\
& Bago Health Centre & 6,41 \\
& Krucil Health Centre & 6,23 \\
& Condong Health Centre & 4,26 \\
& Wonomerto Health Centre & 3,91 \\
& Banyuanyar Health Centre & 5,89 \\
& Krucil Health Centre & 4,85 \\
& Condong Health Centre & 3,91 \\
& Bago Health Centre & 3,86 \\
& Wonomerto Health Centre & 3,58 \\
\hline
\end{tabular}

The condition of home sanitation that meets the health requirements in Probolinggo Regency in 2015 was $64.14 \%$ of the total population. This number decreased in 2016 to $53.14 \%$ and increased again to $67.40 \%$ in 2017 (Table 2).

Access to improved drinking water in Probolinggo Regency increased from 2015 to 2017. Drinking water access in Probolinggo Regency reached $97.08 \%$ of the total population in
2015. The number increased to $97.27 \%$ in 2016 , dropping to $97 \%$ and $96 \%$ in 2017 (Table 2).

A healthy environment is supported by positive community behaviour. Improving public health to reduce diarrhoea cases can be done through healthy behaviour by including all family members and the community. Healthy hygiene behaviours in Probolinggo Regency increased from 2015 to 2017. In 2015 healthy hygiene behaviours reached $21.33 \%$ of the total households monitored. The number increased to $22.25 \%$ in 2016 and $24.40 \%$ in 2017 (Table 3).

Correlation of Home Sanitation Conditions, Drinking Water Access, and Clean and Healthy Living Behaviour with Diarrhoea Cases in Probolinggo District in 2017

Pearson correlation tests were used to determine the relationship between the incidence of diarrhoea and the conditions of home sanitation, drinking water access, and healthy clean behaviour in Probolinggo District in 2017. The assumption that must be fulfilled before conducting a correlation test is that data are normally distributed. The results of the normality test for the condition of home sanitation were normally distributed with a $p$ value $=0.73 ; p>0.05$. The drinking water access variable was normally distributed with a value of $\mathrm{p}=1.87 ; \mathrm{p}>0.05$. Clean and healthy behavioural variables were also normally distributed with $\mathrm{p}=1.05 ; \mathrm{p}>0.05$. The overall assumption of these results was fulfilled and Pearson correlation tests were able to be carried out (Table 5).

Table 2

Profile of Sanitary Conditions for Houses and Drinking Water Access per Total Population in Probolinggo Regency in 2015-2017

\begin{tabular}{lrrrrr}
\hline \multirow{2}{*}{ Years } & \multirow{2}{*}{ Total Population } & \multicolumn{2}{c}{ Sanitary Conditions for Houses } & \multicolumn{2}{c}{ Drinking Water Access } \\
\cline { 3 - 6 } & & $\mathrm{n}$ & $\%$ & $\mathrm{n}$ & $\%$ \\
\hline 2015 & 1.140 .480 & 731.509 & 64,14 & 1.107 .235 & 97,08 \\
2016 & 1.148 .021 & 610.066 & 53,14 & 1.116 .654 & 97,27 \\
2017 & 1.156 .128 & 779.006 & 67,40 & 1.132 .513 & 97,96 \\
\hline
\end{tabular}

Table 3

Profile of Clean and Healthy Living Behaviour in Total Houses Monitored in Probolinggo Regency in 20152017

\begin{tabular}{lrrrr} 
& \multirow{2}{*}{ Years } & \multirow{2}{*}{ Total Houses Monitored } & \multicolumn{2}{c}{ Clean and Healthy Living Behaviour } \\
\cline { 3 - 4 } & & 16.322 & Total & $(\%)$ \\
\hline 2015 & 66.846 & 14.882 & 21,33 \\
2016 & 85.284 & 20.652 & 22,25 \\
2017 & & & 24,40 \\
\hline
\end{tabular}


Table 4

Normality Test Results for Home Sanitation Conditions, Drinking Water Access, and Clean and Healthy Living in Relation to Diarrhoea Incidents

\begin{tabular}{lr}
\hline \multicolumn{1}{c}{ Category } & Results \\
\hline Home Sanitation Conditions & 33 \\
N & 0,73 \\
Kolmogorov-Smirnov Z & 0,65 \\
Asymp. Sig.(2-tailed) & \\
Drinking Water Access & 33 \\
N & 1,87 \\
Kolmogorov-Smirnov Z & 0,00 \\
Asymp. Sig.(2-tailed) & \\
Clean and Healthy Living & 33 \\
N & 1,05 \\
Kolmogorov-Smirnov Z & 0,22 \\
Asymp. Sig.(2-tailed) & \\
Diarrhoea Incidents & 33 \\
N & 0,98 \\
Kolmogorov-Smirnov Z & 0,28 \\
Asymp. Sig.(2-tailed) & \\
\hline
\end{tabular}

The Pearson correlation between home sanitation conditions and the incidence of diarrhoea from all health centres in Probolinggo district was 0.07 . The relationship is very weak but positive, meaning that the higher (better) the home sanitation, the lower the incidence of diarrhoea (Table 5).

The Pearson correlation between access to drinking water and the incidence of diarrhoea was 0.02 . The relationship is very weak but positive, meaning that the higher (better) access to drinking water, the lower the incidence of diarrhoea (Table $5)$.

The Pearson correlation between clean and healthy living behaviour and the incidence of diarrhoea was 0.03 . The relationship is very weak and negative, meaning that the lower (less) the hygiene behavior, the higher the incidence of diarrhoea (Table 5).

\section{DISCUSSION}

\section{Overview of Diarrhoea Incidents in each Health Centre in Probolinggo Regency in 2015-2017}

Diarrhoea is a problem in the community that is often experienced by all age groups. The prevalence of diarrhoea in Probolinggo Regency in 2017 for all age groups was 2.43\%. The occurrence of diarrhoea in Probolinggo Regency in 2017 occurs mostly in rural areas around the mountains and land (Probolinggo District Health Office, 2018).

Morbidity and mortality rates for environmental diseases are still a health problem in Indonesia with a high number of cases. Such events are still common in rural areas (Apriyanti, Widjanarko, \& Laksono, 2019), although research conducted by Alma, Widowati, \& Wibowo (2018) found that there was no relationship between the area of residence and the incidence of diarrhoea.

The data contained in the Probolinggo District Health Profile in 2015-2017 illustrates that there are five health centres with the highest prevalence of diarrhoea. Bago Health Centre for the past three years has been recorded as one that has contributed the most to the incidence of diarrhoea in Probolinggo Regency. The working area of Bago Health Centre is in Besuk District with a population density of 1375.80 per $\mathrm{km}^{2}$ (Probolinggo District Health Office, 2018).

The mechanism of transmission of diarrhoea is faecal-oral. It is probable that the microorganisms inside the body that cause diarrhoea enter via food or drink that has been contaminated with human faeces or stools, spread through vector intermediaries (Arimbawa, Dewi, \& Ahmad, 2016). Transmission of diarrhoea is not only caused by human-excrement contaminated food and beverages, but by improper disposal of infants' faeces. The perception that toddler stool does not endanger health is not true. Toddler stool contains microorganisms that can also cause diarrhoeal diseases; the same applies to animal stool (Rahmadian, Ketaren, \& Sirait, 2017).

Lack of environmental hygiene and poor sanitation are the dominant factors that cause diarrhoea. If these two factors can be controlled properly, all other factors can contribute to reducing the incidence of diarrhoea (Dewi, Madiastuti, \& Yuliantini, 2017).

Table 5

Pearson Correlation Test Result on Percentage of Home Sanitation Condition, Drinking Water Access, and Clean and Healthy Clean Living Behaviour with Diarrhoea Incidents in Probolinggo Regency 2017

\begin{tabular}{lcrrr}
\hline Prevalence of diarrhoea & $\begin{array}{c}\text { Home Sanitation } \\
\text { Conditions }\end{array}$ & $\begin{array}{c}\text { Drinking water } \\
\text { access }\end{array}$ & $\begin{array}{c}\text { Clean and healthy living } \\
\text { behaviour }\end{array}$ \\
\hline Pearson Correlation & & 0,07 & 0,02 & 0,03
\end{tabular}


The level of threat of an outbreak of diarrhoeal diseases is determined by several other factors. Two of the determining factors are access to clean water and the availability of proper latrines (Rahmawati \& Faisal, 2019).

\section{Analysis of Correlation of Home Sanitation Conditions, Drinking Water Access, and Clean and Healthy Living Behaviour with Diarrhoea Events in Probolinggo District in 2017}

Diarrhoea is an environmental disease - i.e. it comes from the environment and not from genetics or other factors. It is related to the living conditions and behaviour of the community itself. Diarrhoea has the potential to cause death, especially during an outbreak (Probolinggo District Health Office, 2018). Control of environmental conditions can contribute to minimising the incidence of diarrhoea, such as access to healthy latrines or access to portable clean water accompanied by clean and healthy community behaviour (Hartati \& Nurazila, 2018).

Based on the results of the study, there is a very weak correlation between the condition of home sanitation and the incidence of diarrhoea in Probolinggo Regency in 2017. The direction of correlation is positive, which means that the higher (better) the home sanitation, the lower the incidence of diarrhoea. Research conducted by Rahman, Widoyo, Siswanto, \& Biantoro (2016) shows that the incidence of diarrhoea will increase along with reduced access to healthy latrines, and vice versa. This is in line with the research conducted by Purwanto, Miswan, \& Yani (2018), which shows that there is a correlation between toilet conditions and the incidence of diarrhoea in infants. Other research also shows the same thing - that there is a correlation between latrine conditions and the incidence of diarrhoea (Usman, Nursalim, \& Darmawan, 2018). This is not, however, in line with research that found no correlation between the use of clean latrines and the incidence of diarrhoea in infants (Grafika, Sabilu, \& Munandar, 2017).

A latrine is one of the requirements for a healthy home as a place for disposal of faeces. The availability of latrines maintains clean environmental conditions and avoids various potential diseases that can be transmitted through faeces (East Java Provincial Health Office, 2018). This is in line with the results of research conducted by Ulfayanti, Sudirman, \& Budiman (2018), which shows a relationship between toilet ownership and diarrhoeal disease. If the community can access a toilet properly, this will not only minimise the odour caused by faeces, and unpleasant sights, it can minimise the spread of diseases caused by faecal pollution (Ministry of Health RI, 2018). The condition of latrines must be considered to realise proper sanitation and not to spread microorganisms that cause diarrhoeal diseases (Sidhi, Raharjo, \& Dewanti, 2016).

The results also show that there is a very weak correlation between access to drinking water and the incidence of diarrhoea in Probolinggo District in 2017 and it is in the direction of a positive linear correlation, which means that the higher (better) access to drinking water, the lower the incidence of diarrhoea.A study confirms a correlation between clean water facilities and the incidence of diarrhoea in infants (Samiyati, Suhartono, \& Dharminto, 2019). The condition of clean water facilities minimised the incidence of diarrhoeal diseases. Other studies have shown similar results - i.e. that the condition of clean water facilities is related the reduced incidence of diarrhoea (Langit, 2016).

The quality of drinking water is also a consideration. Escherichia coli bacteria is one of the causes of diarrhoea, especially in infants. This explanation is supported by the results of research that confirm that there is a correlation between the bacteriological quality of drinking water and the incidence of diarrhoea (Aini, Raharjo, \& Budiyono, 2016).

Water is a resource that must be had to maintain life and health, but poor quality water can itself cause disease. Diseases that can be transmitted to humans via water conditions contaminated by microorganisms or certain substances are often referred to as waterborne diseases (Rasako, Joko, \& Dangiran, 2018).

Probolinggo Regency has carried out preventive actions to minimise the occurrence of environmental-based diseases and improve community health status through the establishment of Probolinggo Regent Regulation number 32 of 2016 concerning the Community-Based Total Sanitation Movement in Probolinggo District. The determination was in order to implement a commitment of the regional government to achieve improvements in access to drinking water and basic sanitation through the acceleration of the community-based sanitation movement for Probolinggo District (Hartati \& Nurazila, 2018). 
The results showed that there was a very weak correlation between clean and healthy living behaviour and the incidence of diarrhoea in Probolinggo District in 2017, and it is in the direction of a negative linear correlation, meaning that the lower the hygiene behaviour, the higher the incidence of diarrhoea. This research is in line with other studies that prove that there is a correlation between public health behaviour and the incidence of diarrhoea (Megasari, Hidayat, Chairuddin, \& Santoso, 2015).

Clean and healthy living in the household is behaviour based on making all family members self-aware in terms of health. The application of good hygiene can prevent diarrhoea through exclusive breastfeeding of infants, hand-washing habits, and maintaining environmental factors including the use of clean water and healthy latrines (Probolinggo District Health Office, 2018). This explanation is in line with other studies that show that there is a relationship between hygiene (e.g. hand-washing after defecation) and the incidence of diarrhoea in the elderly in Indonesia (Sumolang, Nurjana, \& Widjaja, 2019). Washing hands with soap before feeding a child, before touching food, before eating, and after defecating are all efforts to be free of germ pollution (Selviana, Trsinawati, \& Munawarah, 2017)

\section{Research Limitations}

This study has weaknesses related to the dependent variable and the independent variables taken from the overall secondary data based on the 2017 Probolinggo District Health Profile. Thus, the correlated data is aggregate data, which may result in statistical calculations containing bias.

\section{CONCLUSION}

The incidence of diarrhoea in Probolinggo District in 2017 decreased from the previous two years. Bago Health Centre contributed the highest number of diarrhoea cases in the three years from 2015 to 2017 . There is a very weak correlation between the condition of home sanitation, access to drinking water, and clean and healthy living behaviour and the incidence of diarrhoea, with each direction of the relationship being positive and negative for clean and healthy behavioural variables. The Probolinggo District Health Office and related sectors should pay attention to the dominant factors that have a positive linear correlation direction in order to prevent the incidence of diarrhoea.

\section{ACKNOWLEDGEMENT}

The author would like to thank all parties who have provided support and guidance to complete the preparation of this research.

\section{REFERENCES}

Aini, N., Raharjo, M., \& Budiyono. (2016). The relationship of drinking water quality with the incidence of diarrhea in infants in the working area of Banyuasin Health Center, Loano District. Jurnal Kesehatan Masyarakat (e-Journal), 4(1), 399-406.

Alma, L. R., Widowati, T., \& Wibowo, T. A. (2018). Social determinants of the incidence of acute diarrhea in children aged 0-59 months in Purworejo. Berita Kedokteran Masyarakat, 33(7), 365-370. https://doi.org/10.22146/bkm.18150

Apriyanti, L., Widjanarko, B., \& Laksono, B. (2019). Factors that influence the use of family latrines in Jatibarang District, Brebes Regency. Jurnal Promosi Kesehatan Indonesia, 14(1), 1-14.

Arimbawa, I. W., Dewi, K. A. T., \& Ahmad, Z. bin. (2016). The relationship between behavioral factors and environmental factors on the incidence of diarrhea in infants in Sukawati Village, Gianyar Regency, Bali in 2014. Intisari Sains Medis, 6(1), 8-15.

Azhar, K., Siska, D., \& Hapsari, D. T. (2015). Diarrhea in toddler at DKI Jakarta Province in terms of drinking water, sanitation and PHBS aspects (riskesdas 2013 data analysis). Jurnal Ekologi Kesehatan, 14(1), 29-40.

Blum, H. L. (1974). Planning for health: development and application of social change theory. New York: Human Sciences Press.

Dewi, A., Madiastuti, M., \& Yuliantini, S. (2017). Factors related to the incidence of diarrhea in children aged 12-36 months in the Cijoro Pasir village, the working area of the Rangkasbitung Public Health Center, Lebak Regency, Bantun Province, 2017. Ilmu Dan Budaya, 41(59), 6913-6926.

East Java Provincial Health Office. (2018). East Java Province health profile in 2017. Kota Surabaya.

Grafika, D., Sabilu, D. Y., \& Munandar, S. (2017). Risk factors for lack of clean and healthy life behavior (PHBS) household arrangements for the incidence of diarrhea in toddlers in the working area of Benu-continent Puskesmas 
Kendari City in 2017. Jurnal Ilmiah Mahasiswa Kesehatan Masyarakat, 2(7), 110.

Hartati, S., \& Nurazila. (2018). Factors affecting the incidence of diarrhea in infants in the working area of Pekanbaru Rejosari Health Center. Jurnal Endurance, 3(2), 400-407.

Jannah, M., \& Maftukhah, N. A. (2018). Relationship between community behavior, settler distance and fly density with the occurrence of diarrhea in settlements around chicken farms in Rambang Muara Enim District. Masker Medika, 6(2), 461-471.

Langit, L. S. (2016). The relationship of basic sanitation conditions at home with the incidence of diarrhea in infants in the work area of the Rembang Community Health Center 2. Jurnal Kesehatan Masyarakat (eJournal), 4(2), 160-165.

Mardotillah, M., Gunawan, B., Soemarwoto, R. S., \& Raksanagara, A. S. (2018). The role of enabling and reinforcing factors in access to healthy urban latrines. Jurnal Antropologi, 20(2), 165-178.

Megasari, Hidayat, T., Chairuddin, G., \& Santoso, I. (2015). Public health behavior towards the occurrence of diarrhea based on aspects of environmental sanitation in Barito District

Kuala. Environmental Science and Technology, 11(33-40), 33-40.

Ministry of Health RI. (2018). Indonesia's health profile in 2017. Jakarta: Ministry of Health RI.

Na, L., \& Streim, J. E. (2017). Psychosocial wellbeing associated with activity of daily living stages among community-dwelling older adults. Gerontology \& Geriatric Medicine, $3(1)$, $1-13$. https://doi.org/10.1177/2333721417700011

Probolinggo District Health Office. (2018). Probolinggo District health profile in 2017. Probolinggo District Health Office.

Purwanto, I. W. H., Miswan, \& Yani, A. (2018). The relationship of basic sanitation with the occurrence of diarrhea in children under five in the work area of Talise Health Center, Mantikulore District, Palu City. Jurnal Kolaboratif Sains, 1(1), 360-372.

Rahmadian, S., Ketaren, O., \& Sirait, A. (2017). Factors related to the incidence of diarrhea in the Ngkeran Health Center in Southeast Aceh District in 2017. Jurnal Ilmiah Simantek, 1(3), 64-79.

Rahman, H. F., Widoyo, S., Siswanto, H., \& Biantoro. (2016). Factors related to the incidence of diarrhea in Solor Village, Cermee Bondowoso District. NurseLine Journal, 1(1), 24-35. https://doi.org/25407937

Rahmawati, \& Faisal, M. (2019). Analisis cluster untuk pengelompokan desa berdasarkan indikator penyakit diare. Saintifik, 5(1), 7580.

Rasako, R. F., Joko, T., \& Dangiran, H. L. (2018). The relationship of bacteriological quality of dug well water and the incidence of diarrhea in Waihaong Village, Ambon City. Jurnal Kesehatan Masyarakat (e-Journal), 6(2), 143-150.

Samiyati, M., Suhartono, \& Dharminto. (2019). Relationship between home environmental sanitation and the incidence of diarrhea in infants in the working area of Karanganyar Health Center, Pekalongan Regency. Jurnal Kesehatan Masyarakat (e-Journal), 7(1), 388-395.

Selviana, Trsinawati, E., \& Munawarah, S. (2017). Factors associated with the incidence of diarrhea in children aged 4-6 years. Jurnal Vokasi Kesehatan, 3(1), 28-34.

Sidhi, A. N., Raharjo, M., \& Dewanti, N. A. Y. (2016). Relationship between the quality of environmental sanitation and clean water bacteriology to the incidence of diarrhea in infants in the work area of the Adiwerna Health Center in Tegal Regency. Jurnal Kesehatan Masyarakat (e-Journal), 4(3), 665-676.

Sumolang, P. P., Nurjana, M. A., \& Widjaja, J. (2019). Analysis of drinking water and hygiene behavior with the incidence of diarrhea in the elderly in Indonesia. Media Penelitian Dan Pengembangan Kesehatan, 29(1), 99-106. https://doi.org/10.22435/mpk.v29i1.123

Ulfayanti, Sudirman, \& Budiman. (2018). The relationship of environmental sanitation conditions with diarrheal disease in $\mathrm{Nalu}$ Village, Baolan District, Tolitoli Regency. Jurnal Kolaboratif Sains, 1(1), 849-856. https://doi.org/10.31934/jom.v1i1.421

Usman, M. H., Nursalim, \& Darmawan, S. (2018). The relationship between clean and healthy life behavior (PHBS) and the incidence of diarrhea in the Samataring Community Health Center, East Sinjai District, Sinjai District. Jurnal Ilmiah Kesehatan Diagnosis, 12(1), 75-80. 